\title{
Physical, chemical and mechanical wood properties of Pinus nigra growing in Portugal
}

\author{
Alexandra Dias ${ }^{1}$ - Ana Carvalho ${ }^{1,2,3}$ - Maria Emília Silva ${ }^{1,4}$ • José Lima-Brito ${ }^{1,2,3}$ - Maria João Gaspar ${ }^{2,3,5} \cdot$ Ana Alves $^{5}$. \\ José Carlos Rodrigues ${ }^{5}$ • Fábio Pereira ${ }^{1}$ • José Morais ${ }^{1}$ • José Luís Lousada ${ }^{1,4}$ (D)
}

Received: 3 May 2020 / Accepted: 15 July 2020 / Published online: 22 July 2020

(C) INRAE and Springer-Verlag France SAS, part of Springer Nature 2020

\begin{abstract}
- Key message The wood of Pinus nigra populations planted in Portugal, comparatively to Pinus pinaster, has higher total extractive content, lower Klason lignin and $\mathrm{H} / \mathrm{G}$ ratio, and similar mechanical properties, presenting advantages for industrial purposes.

- Context P. nigra was used in the reforestation of mountainous areas in Portugal, but its wood chemical and mechanical properties were never studied.

- Aims This work intends to evaluate the chemical and mechanical wood properties of the $P$. nigra populations planted in Portugal, to relate these properties with previously characterised physical features and to compare these data with other European $P$. nigra stands and species, namely, $P$. pinaster.

- Methods Wood chemical and mechanical properties were analysed in 90 trees from six Portuguese sites, using near-infrared (NIR) spectrometry and the three-point bending test.

- Results The wood of the $P$. nigra populations planted in Portugal presented average values of total extractive content $=9.4 \%$, Klason lignin $=26.69 \%, \mathrm{MOR}_{\mathrm{Rad}}=14.93 \mathrm{MPa}$ and $\mathrm{MOE}_{\mathrm{Rad}}=1200.98 \mathrm{MPa}$. Ring density showed no significant correlation with ring width. - Conclusion The P. nigra populations planted in Portugal presented qualitative and quantitative properties similar to $P$. pinaster wood, the main resinous species in Portugal. Facing the lack of raw material for wood industry due to frequent forest fires in the Mediterranean region, P. nigra could be used to reforest mountainous areas of those regions.
\end{abstract}

Keywords European black pine $\cdot$ NIR spectrometry $\cdot$ MOE radial and MOR radial $\cdot$ Wood density $\cdot$ X-ray microdensitometry

Handling Editor: Jean-Michel Leban

Contribution of the co-authors Conceptualisation: JCR, JM, and JLL; methodology: JCR, JM, and JLL; formal analysis: JCR, JM, and JLL; investigation: JLL, AA, and FP; resources: MJG, MES, JLL, and JLB; writing: JLL; writing-review and editing: JLL, JLB, AC, and JCR; supervision: JLL; project administration: JLL and AC; MJG funding acquisition: JLL

José Luís Lousada jlousada@utad.pt

Alexandra Dias

xana_dias@hotmail.com

Ana Carvalho

anacar@utad.pt

Maria Emília Silva

emil_ms@utad.pt

José Lima-Brito

jbrito@utad.pt

Maria João Gaspar

mjgaspar@utad.pt

\author{
Ana Alves \\ analves@isa.ulisboa.pt \\ José Carlos Rodrigues \\ jocarod@isa.ulisboa.pt \\ Fábio Pereira \\ fampereira@gmail.com \\ José Morais \\ jmorais@utad.pt
}

Extended author information available on the last page of the article 


\section{Introduction}

Pinus nigra Arnold is used in the reforestation of mountainous areas due to its ability to grow in high altitudes (Naydenov et al. 2006). It is considered a relict species with a broad and fragmented distribution that ranges from the North of Africa, Northern Mediterranean, Eastwards to the Black Sea, Corsica and Sicily islands (Afzal-Rafii and Dodd 2007). Because of the different ecological pressures (Thompson 2005), this species manifests high variation among populations (del Cerro Barja et al. 2009; Rubio-Moraga et al. 2012; Dias et al. 2019), occupying a wide variety of sites (Barbéro et al. 1998; Génova and Cancio 1998).

In Portugal, P. nigra was planted in the middle of the twentieth century at the North and Centre (Louro 1982). Although the populations are between 50 and 90 years old, its wood characteristics were just studied in the current years (Dias et al. 2018, 2019).

Wood properties variation is mainly influenced by the growth pattern (Downes et al. 2000) and its biological origin (Zobel and van Buijtenen 1989). There is variation within the tree from pith to bark and within each annual ring from earlywood to latewood (Zobel and Sprague 1998). This large variability poses difficulties on the prediction of the wood performance and therefore, the efficiency of its processing and use (Koga and Zhang 2004). The definition of wood quality is dependent of its properties for specific end-use, with density as the more significant, followed by other features such as chemical composition (the content of cellulose, hemicellulose and lignin) and mechanical properties (modulus of elasticity and rupture) (Zobel and van Buijtenen 1989).

Wood density is the main responsible for the timber strength, pulp yield, ease of drying, machining and hardness (Elliot 1970; Brazier and Howell 1979; Panshin and Zeeuw 1980). This wood property is the result of the ratio between cell size and wall thickness, proportion of earlywood and latewood, and the number of ray cells, vessel elements and chemical content (Zobel and van Buijtenen 1989; Cave and Walker 1994). In what concerns the wood chemical composition (cellulose, hemicellulose, lignin and extractive components) and its variation is vital for a part of the forestry industry, such as the pulp industry. In this case, to achieve high pulp yield and brightness of the bleached paper, it should have high cellulose, low extractive content and lignin (Campbell and Sederoff 1996; Üner et al. 2009). Besides, chemical composition also influences the mechanical properties of particle boards (Üner et al. 2009).

The mechanical properties of wood pose interest in several areas of engineering for the selection and application of wood for specific end-use. This knowledge will allow its mechanical characterisation for comparison with other materials (Santos and Pinho 2004). Two of the properties most commonly measured are the modulus of elasticity and rupture, used for the evaluation of wood quality for structural components (Green et al. 1999).
$P$. nigra is widely used in the forestry industry due to its aptitude to grow in different environments, with suitable outcoming products (Üner et al. 2009). Also, it is recognised for its mechanical strength for structural refurbishing and construction (Fernández-Golfín Seco et al. 2004). Moreover, the main resinous species in Portugal used for industrial purposes, Pinus pinaster Ait., is reducing, increasing the timber demands and importation of raw material (Uva 2015). In this sense, this work aims to answer the following:

- What is the relation found between chemical, mechanical and previously achieved physical properties (density and growth; Dias et al. 2018) of P. nigra planted in Portugal?

- Are the wood properties of this species similar to those of other European natural stands and species including $P$. pinaster, the main resinous species used to supply the softwood national demands?

\section{Material and methods}

P. nigra allochthonous populations were planted mainly in high altitude mountains in the North and Centre of Portugal. Six populations representative of its distribution, with an altitude range of 450 to $1600 \mathrm{~m}$, were sampled (Table 1). More detailed information about the sample sites characterisation can be found in Dias et al. (2018). In each sample plot (0.04 ha), dendrometric measurements were performed in all trees, and a total of 90 dominant and codominant trees ( 15 per plot) were sampled. In each tree, wood cores of $12 \mathrm{~mm}$ from bark to pith to bark were sampled at the breast height. Samples with lower reaction wood were chosen.

It was analysed the chemical composition (macromolecules) with the near-infrared (NIR) spectrometric method and mechanical features by using a three-point bending test. The wood density and growth were studied previously in Dias et al. (2018) and those results were used here in the correlation matrix for the analysis of all the components: density, growth, chemical and mechanical properties.

For the evaluation of the chemical properties per tree, it was used the wood material of the opposite radial strip used in the microdensitometry. The tree samples were milled in a Retsch Ultra Centrifugal Mill ZM 100 with a 1-mm screen sieve for posterior Soxhlet extraction with dichloromethane, ethanol and water. Finally, the extracted material was oven-dried at $45{ }^{\circ} \mathrm{C}$ for 2 days. NIR spectra were recorded on a Bruker MPA spectrometer (Bruker Optics, Ettlingen, Germany) equipped with a spinning cup module. The spectra were acquired in diffuse reflectance mode using an integration sphere in the wavenumber range from 12,000 to $4000 \mathrm{~cm}^{-1}$, at a spectral resolution of $8 \mathrm{~cm}^{-1}$, each spectrum resulted from the average of 100 spectra and a zero filling of two was applied (Alves et al. 2006; Schwanninger et al. 2011a). Extractive-free samples were dried at $60{ }^{\circ} \mathrm{C}$ 
Table 1 P. nigra sampled sites and dendrometric data (Dias et al. 2018)

\begin{tabular}{|c|c|c|c|c|c|c|}
\hline & Paredes de Coura & Caminha & Vila Pouca de Aguiar & Campeã & Manteigas & Vale do Zêzere \\
\hline Number of individuals & 15 & 15 & 15 & 15 & 15 & 15 \\
\hline Coordinates & $\begin{array}{l}41^{\circ} 52^{\prime} 0.00^{\prime \prime} \mathrm{N} \\
8^{\circ} 36^{\prime} 21.00^{\prime \prime} \mathrm{W}\end{array}$ & $\begin{array}{l}41^{\circ} 50^{\prime} 15.00^{\prime \prime} \mathrm{N} \\
8^{\circ} 43^{\prime} 57.00^{\prime \prime} \mathrm{W}\end{array}$ & $\begin{array}{l}41^{\circ} 31^{\prime} 02.72^{\prime \prime} \mathrm{N} \\
7^{\circ} 35^{\prime} 31.36^{\prime \prime} \mathrm{W}\end{array}$ & $\begin{array}{l}41^{\circ} 19^{\prime} 9.12^{\prime \prime} \mathrm{N} \\
7^{\circ} 53^{\prime} 28.35^{\prime \prime} \mathrm{W}\end{array}$ & $\begin{array}{l}40^{\circ} 22^{\prime} 47.00^{\prime \prime} \mathrm{N} \\
7^{\circ} 33^{\prime} 18.00^{\prime \prime} \mathrm{W}\end{array}$ & $\begin{array}{l}40^{\circ} 19^{\prime} 19.00^{\prime \prime} \mathrm{N} \\
7^{\circ} 34^{\prime} 26.00^{\prime \prime} \mathrm{W}\end{array}$ \\
\hline Average age \pm SD & $57.8 \pm 1.1$ & $57.9 \pm 1.3$ & $74.7 \pm 2.9$ & $58.1 \pm 1.5$ & $93.3 \pm 2.8$ & $59.1 \pm 1.6$ \\
\hline Average height (m) & 14.8 & 26.3 & 26.8 & 23.1 & 24.4 & 15.0 \\
\hline Average diameter at $1.3 \mathrm{~m}(\mathrm{~cm})$ & 21.1 & 32.6 & 40.1 & 37.1 & 34.1 & 24.8 \\
\hline Stand density (trees/ha) & 975 & 725 & 475 & 650 & 525 & 700 \\
\hline Altitude & 451 & 443 & 908 & 891 & 1144 & 1560 \\
\hline
\end{tabular}

overnight and kept in a desiccator until ready for analysis. The oven-dried and extractive-free Klason lignin content and extractive-free $\mathrm{H} / \mathrm{G}$ ratio were assessed by NIR-based PLS-R models with software OPUS-Quant (Bruker Optics, Ettlingen, Germany). These models have prediction errors of $0.18 / 0.18$ (RMSEC/RMSECV) for Klason lignin content and 0.002/0.003 (RMSEC/RMSECV) H/G ratio (Alves et al. 2019). These models were similar to the ones applied in Picea abies (Schwanninger et al. 2011a, b) and Pinus sylvestris (Fernandes et al. 2017).

Concerning the radial mechanical properties, the same strips from the microdensitometric analysis were used, i.e. obtained from the wood cores of $12 \mathrm{~mm}$ sampled at the breast height. One pith-to-bark strip was sawn from each core with approximately dimension of $5 \mathrm{~mm}$ (tangential) $\times 3 \mathrm{~mm}$ (axial) $\times$ stem radius (radial). For each sample, $\mathrm{MOE}_{\mathrm{Rad}}$ (modulus of elasticity in radial direction) and $\mathrm{MOR}_{\mathrm{Rad}}$ (modulus of rupture in radial direction) were evaluated through three-point bending tests (Brancheriau et al. 2002; Yoshihara and Tsunematsu 2006; Gaspar et al. 2011), in which it was only necessary to adapt the size and orientation of the wood samples. Before testing, the specimen dimensions (tangential and axial) were measured with a digital calliper (0.01-mm resolution). Bending tests were carried out at room temperature with an electromechanical testing machine (Instron 5848 MicroTester®) with a $0.5-\mathrm{mm} / \mathrm{min}$ displacement control and $40 \mathrm{~mm}$ span.

Table 2 Mean values ( \pm standard deviation) and results of the comparison test for chemical and mechanical properties. (Dichloro): extractives soluble in dichloromethane (\%); (ethanol): extractives soluble in ethanol (\%); (water): extractives soluble in water (\%); (total): total extractives $(\%)$; (Klason): lignin content $(\%)$; $(\mathrm{H} / \mathrm{G})$ : lignin

\section{Results}

\subsection{Chemical wood properties}

In average, the $P$. nigra populations planted in Portugal had a total of extractive content of $9.4 \%$, mainly removed by dichloromethane $(5.6 \%)$ followed by water $(2.2 \%)$ and ethanol (1.6\%). The Klason lignin was of $26.69 \%$, and the $\mathrm{H} / \mathrm{G}$ ratio was 0.041 .

In terms of total extractive content and dichloromethane extraction solvent, the site that presented higher value was Vila Pouca de Aguiar, while Campeã showed the lowest value. Between the remaining solvents, the differences were not statistically significant $(p>0.05)$. Regarding the Klason lignin, the higher values were observed in Caminha, Campeã and Vale do Zêzere (ranging from 27.02 to $27.38 \%$ ). In comparison, the remaining sites did not present statistical differences $(p>0.05)$ among them $(25.61$ to $26.73 \%)$. A similar trend was found in the $\mathrm{cP} / \mathrm{cH}$, with the highest values in Campeã and Vale do Zêzere but with no significant differences $(p>0.05)$ relative to the remaining sites. In the $\mathrm{H} / \mathrm{G}$ case, globally, the differences were very reduced and not significant $(p>0.05)$, being noteworthy the higher value presented by Vale de Zêzere (0.044) (Table 2).

composition (\%); (cP/cH): pentose/hexose ratio; $\left(\mathrm{MOE}_{\mathrm{Rad}}\right)$ : radial modulus of elasticity $(\mathrm{MPa})$; $\left(\mathrm{MOR}_{\mathrm{Rad}}\right)$ : radial modulus of rupture $(\mathrm{MPa})$. Different letters in the same column indicate significant differences $(p<0.05)$ between sampled sites after Duncan's multiple range test

\begin{tabular}{|c|c|c|c|c|c|c|c|c|c|}
\hline Site & Dicloro & Ethanol & Water & Total & Klason & $\mathrm{H} / \mathrm{G}$ & $\mathrm{cP} / \mathrm{cH}$ & $\mathrm{MOR}_{\mathrm{Rad}}$ & $\mathrm{MOE}_{\mathrm{Rad}}$ \\
\hline All & 5.6 & 1.6 & 2.2 & 9.4 & 26.69 & 0.041 & 10.07 & 14.93 & 1200.98 \\
\hline Paredes de Coura & $6.0 \mathrm{bc}$ & $1.4 \mathrm{a}$ & $2.3 \mathrm{a}$ & $9.7 \mathrm{~b}$ & $26.14 \mathrm{ab}$ & $0.040 \mathrm{ab}$ & $9.62 \mathrm{a}$ & $14.15 \mathrm{a}$ & $1258.25 \mathrm{ab}$ \\
\hline Caminha & $4.7 \mathrm{ab}$ & $1.4 \mathrm{a}$ & $2.1 \mathrm{a}$ & $8.2 \mathrm{ab}$ & $27.38 \mathrm{c}$ & $0.040 \mathrm{a}$ & $9.46 \mathrm{a}$ & $13.44 \mathrm{a}$ & $1216.76 \mathrm{ab}$ \\
\hline Vila Pouca de Aguiar & $8.1 \mathrm{c}$ & $2.0 \mathrm{~b}$ & $2.7 \mathrm{a}$ & $12.9 \mathrm{c}$ & $25.61 \mathrm{a}$ & $0.040 \mathrm{ab}$ & $9.40 \mathrm{a}$ & $13.95 \mathrm{a}$ & $1068.56 \mathrm{a}$ \\
\hline Campeã & $3.2 \mathrm{a}$ & $1.4 \mathrm{a}$ & $2.0 \mathrm{a}$ & $6.6 \mathrm{a}$ & $27.24 \mathrm{c}$ & $0.042 \mathrm{ab}$ & $10.74 \mathrm{~b}$ & $17.49 \mathrm{~b}$ & $1235.78 a b$ \\
\hline Manteigas & $5.9 \mathrm{bc}$ & $1.7 \mathrm{ab}$ & $2.0 \mathrm{a}$ & $9.6 \mathrm{~b}$ & $26.73 \mathrm{bc}$ & $0.040 \mathrm{ab}$ & $9.99 \mathrm{a}$ & $12.47 \mathrm{a}$ & $1137.65 \mathrm{ab}$ \\
\hline Vale do Zêzere & $5.8 \mathrm{~b}$ & $1.5 \mathrm{a}$ & $2.0 \mathrm{a}$ & $9.3 \mathrm{~b}$ & $27.02 \mathrm{c}$ & $0.044 \mathrm{~b}$ & $11.24 \mathrm{~b}$ & $17.47 \mathrm{~b}$ & $1288.85 \mathrm{~b}$ \\
\hline
\end{tabular}




\subsection{Mechanical wood properties}

The average $\mathrm{MOR}_{\mathrm{Rad}}$ and $\mathrm{MOE}_{\mathrm{Rad}}$ obtained for all sites were 14.93 MPa and 1200.98 MPa, respectively. Globally, the differences among sites were small. In $\mathrm{MOR}_{\mathrm{Rad}}$, the higher values were detected in Campeã and Vale do Zêzere (17.49 $\mathrm{MPa}$ and $17.47 \mathrm{MPa}$, respectively), while the differences among the remaining sites (ranging from 12.47 to 14.15 MPa) were not significant $(p>0.05)$. Regarding the $\mathrm{MOE}_{\mathrm{Rad}}$, it is only worth to mention the higher value shown by Vale do Zêzere (1288.85 MPa) and the lower one of Vila Pouca de Aguiar (1068.56 MPa), with no significant differences $(p>0.05)$ among the remaining sites (1137.65 to 1258.25 MPa) (Table 2).

\section{Discussion}

\subsection{Wood density and growth properties}

To consider the main $P$. nigra components that will be correlated and discussed in Section 4.4, a brief resume of the results obtained by Dias et al. (2018) concerning the density and growth components are here mentioned.

The wood of the allochthonous $P$. nigra populations planted in Portugal presented similar RD values found in European stands of the same species. However, upon comparison to other European conifers (Pinus sylvestris, Pinus radiata, Pinus brutia, Picea abies and Abies balsamea), the wood density values was higher, with few minor exceptions (Dias et al. 2018). The heterogeneity index (HI), which confers ring uniformity and homogeneity to the final product (Louzada and Fonseca 2002; Louzada 2003), was similar to the values achieved in $P$. pinaster and $P$. sylvestris growing in Portugal. On the same study, the growth component RW was higher compared to the values obtained in European $P$. sylvestris and $P$. abies, but lower than L. decidua of the Czech Republic and in Portuguese P. sylvestris, Pinus pinea and $P$. pinaster trees.

Regarding the influence of the growth rate on density in the P. nigra growing in Portugal, Dias et al. (2018) showed that the RD is accompanied by higher RW values, except in Paredes de Coura stand, possibly due to site restrictions.

\subsection{Chemical wood properties}

Extractives are one of the main wood components, along with cellulose, hemicelluloses and lignin (Vainio-Kaila et al. 2017). The extractives variation is mainly influenced by the species, but also by its growth conditions, climatic and geographic location, age and genetics of the tree, among others. Nevertheless, in each species, the extractive content varies within specific limits (Hafizoglu 1983). The comparison of our results with other studies should be analysed with attention because of the different tree ages and methodologies used in the extraction procedures, which may result in different outcomes.

Pinus nigra populations planted in Portugal presented a total of extractive content of $9.4 \%$ (dichloromethane, ethanol and water extraction). These values were higher in comparison to the literature review on the subject, which refers that softwoods average values range from 2 to 5\% (Sjöström and Alén 2013). Other studies on the same species reported lower average values, $7.77 \%$ (Uner et al. 2009), 4.65\% (cyclohexane extraction) (Uçar and Balaban 2002), 4.88\% in variety pallasiana and $4.94 \%$ in variety pyramidata (ciclohexane followed by ethanol extraction) (Uçar and Fengel 1995) and 3.2\% (petroleum benzene extraction) (Yildirim and Holmbom 1978). Higher values were found by Uner et al. (2009) in Turkey on $P$. nigra variety pallasiana where the extractive content ranged from 4.30 to $13.0 \%$ and in the Portuguese P. sylvestris, with 10.72 to $15.41 \%$ (dichloromethane, ethanol and water extraction) (Fernandes et al. 2017). In the Portuguese $P$. pinaster, the total extractive content was lower, ranging from 5.5 to 9.6\% (Reva et al. 2015). Other studies in species of younger age (absent or reduced heartwood) revealed lower values in P. sylvestris $(2.9 \%, 27$ years old trees) (Sable et al. 2012), P. pinaster $(4.2 \%, 11$ years old trees) (Fernandes 2006); 4.8\%, 10 years old trees (Da Silva Perez et al. 2007); 6.1\%, 11 years old trees (Gaspar et al. 2011) and P. brutia (7.7\%, 17 to 25 years old) (Üner et al. 2011). Usually, younger trees present lower extractive content, which increases rapidly with age (Gomide et al. 2005; Fernandes et al. 2017). This fact is due to the extractives appearance in high quantity in the heartwood, which only develops in mature wood. Therefore, we can conclude that the extractive content of P. nigra in Portugal showed, in general, higher values when compared with other species. Still, these values were similar in the Portuguese $P$. sylvestris (Fernandes et al. 2017) also growing in high altitudes.

In the present study, the extractives were mainly removed by dichloromethane (5.6\%), followed by water $(2.2 \%)$ and ethanol (1.6\%). Research in Portuguese $P$. sylvestris pointed out that dichloromethane was also the main solvent (7.59 to $12.41 \%$ ), although in this case followed by ethanol (2.18 to $2.29 \%$ ) and water ( 0.53 to $0.96 \%$ ) (Fernandes et al. 2017). In $P$. pinaster studies, the main solvent was water, followed by dichloromethane and ethanol, respectively $3.21 \%, 1.69 \%$ and $1.20 \%$ (Fernandes 2008); 1.8\%, 1.6\% and 1.2\% (Gaspar et al. 
2011); $5.33 \%, 3.32 \%$ and $0.25 \%$ (Reva et al. 2015); $2.0 \%, 1.6 \%$ and $1.2 \%$ (Da Silva Perez et al. 2007).

The Klason lignin content is variable within and among species, influenced by the tree's age and the existence of compression wood, which is related to more lignin and less cellulose (Tsoumis 1991). Concerning to the present study, the $P$. nigra populations planted in Portugal attained a value of $26.68 \%$, which complies with the reference values for pine species, ranging from 26 to $30 \%$ (Zobel and van Buijtenen 1989). Also in P. nigra, Uner et al. (2009) reported values between 14.3 and $34.5 \%$. In other species similar values were presented: $P$. sylvestris 26.9 to $27.8 \%$ (Fernandes et al. 2017), 27.1\% (Sable et al. 2012) and 18.8 to $26.6 \%$ (Toivanen and Alén 2006), Pinus monticola $25 \%$ and Pinus palustris $30 \%$ (Campbell and Sederoff 1996), P. radiata 25.2 to $47.6 \%$ (Cruz et al. 2018), P. pinaster 30.7\% (Da Silva Perez et al. 2007), 27.9\% (Fernandes 2008), 28.1\% (Gaspar et al. 2011) and Pinus caribaea 26.4 to $28.6 \%$ (Godoy et al. 2007).

Very few are still known about the structural lignin composition and its $\mathrm{H} / \mathrm{G}$ ratio ( $p$-hydroxyphenyl/guaiacyl) in pine species, due to the chemical methods normally used (Godoy et al. 2007). The use of the Klason method along with the NIR spectrometric method is a nondestructive and more informative approach (Alves et al. 2006). In this work, the $\mathrm{H} / \mathrm{G}$ ranged from 0.040 to 0.044 . Similar results were obtained in $P$. sylvestris $(0.042$ to 0.048$)$ (Fernandes et al. 2017), P. radiata (0.019 to 0.052) (Nanayakkara et al. 2015) and P. caribaea (0.047 to 0.053) (Godoy et al. 2007). In contrast, slightly higher values were reported in $P$. pinaster $(0.041$ to 0.111$)$ (Da Silva Perez et al. 2007).

Regarding the differences among the six Portuguese sites, the total extractives ranged from $6.6 \%$ in Campeã to $12.9 \%$ in Vila Pouca de Aguiar, which are geographically near but represent the lowest and the maximum values. The Klason lignin was lower in Vila Pouca de Aguiar (25.61\%) and higher in Caminha (27.34\%), followed by Campeã (27.24\%). As for the $\mathrm{H} / \mathrm{G}$ ratio, which is expected to vary just a few within species (Sjöström and Alén 2013), the values were similar among sites. The lowest value of $0.040 \%$ was detected in Paredes de Coura, Caminha, Vila Pouca de Aguiar and Manteigas, and the maximum $(0.044 \%)$ in Vale do Zêzere. Thus, it is possible to conclude that although there is no high distance among sites, there was no consistent tendency detected in terms of its geographic location.

\subsection{Mechanical wood properties}

P. nigra $\mathrm{MOR}_{\mathrm{Rad}}$ and $\mathrm{MOE}_{\mathrm{Rad}}$ values obtained for all sites were 14.92 $\mathrm{MPa}$ and $1204.90 \mathrm{MPa}$, respectively. The $\mathrm{MOE}_{\mathrm{Rad}}$ results were similar to $P$. pinaster and $P$. sylvestris with values ranging from 1100 to $1370 \mathrm{MPa}$ (Fernandes 2008; Gaspar et al. 2011; Fernandes et al. 2017). Regarding the $\mathrm{MOR}_{\mathrm{Rad}}$, the values were similar to $P$. pinaster wood ranging from 13.7 to 14.1 MPa (Fernandes 2008; Gaspar et al. 2011), although much lower than the value of $28.11 \mathrm{MPa}$ obtained by Fernandes et al. (2017) in $P$. sylvestris. In a study performed on younger $P$. radiata trees, lower $\mathrm{MOR}_{\mathrm{Rad}}$ values (7.3 to $7.8 \mathrm{MPa}$ ) were found (Ohbayashi et al. 2001). Regarding the Portuguese sampled sites, the highest MOR values were found in Campeã (17.49 MPa) and Vale do Zêzere (17.47 MPa), while the lowest value was detected in Manteigas (12.47 $\mathrm{MPa})$. The highest MOE values were obtained in Vale do Zêzere (1288.85 MPa) and Paredes de Coura (1258.25 MPa) and the lowest one, in Vila Pouca de Aguiar (1068.56 MPa). In terms of the spatial distribution, it was not detected any trend from North to South, with the highest MOR and MOE values found both in the North and South, which does not seem to reflect any tendency. Also, in terms of altitude, no effects were detected.

\subsection{Correlations among wood features}

Table 3 shows the correlation among all wood features: physical (achieved by Dias et al. 2018), chemical and mechanical properties (this work), computed at the tree level based on the original data (Dias et al. 2020).

Among the extraction solvents, the correlations were positive, with the total extractives higher correlated with dichloromethane $(0.940)$, than with water and ethanol (0.459 and 0.411 , respectively). Also, between the solvents ethanol and water, there was a highly significant correlation (0.412). Similar results were found by Reva et al. (2015) and Fernandes et al. (2017), with a higher correlation between the total extractives and dichloromethane. Fernandes et al. (2017) also found a high correlation between ethanol and water. Klason lignin is highly significantly correlated with $\mathrm{H} / \mathrm{G}$ (0.666), cP_cH (0.700) and strongly correlated with both (0.829). A similar finding was detected in P. sylvestris that showed a high significant correlation between Klason and H/G (Fernandes et al. 2017). Considering the correlations between the chemical (Klason lignin, $\mathrm{H} / \mathrm{G}$ and $\mathrm{cP}$ chanical properties (MOR and MOE), all were very low and statistically not significant. Identical behaviour was found between Klason lignin and the wood density components, where globally the correlations were low and not significant. The exception occurred between Klason and EWW (0.239). Fernandes et al. (2017) did not find correlations but Gaspar et al. (2011) detected in $P$. pinaster a negative correlation between Klason (lignin content) and latewood (LWW and LWP), previously documented in $P$. abies (Hannrup et al. 2004). The correlation between $\mathrm{cP}_{-} \mathrm{cH}$ and the wood density components was, in general, negative, and in some cases 


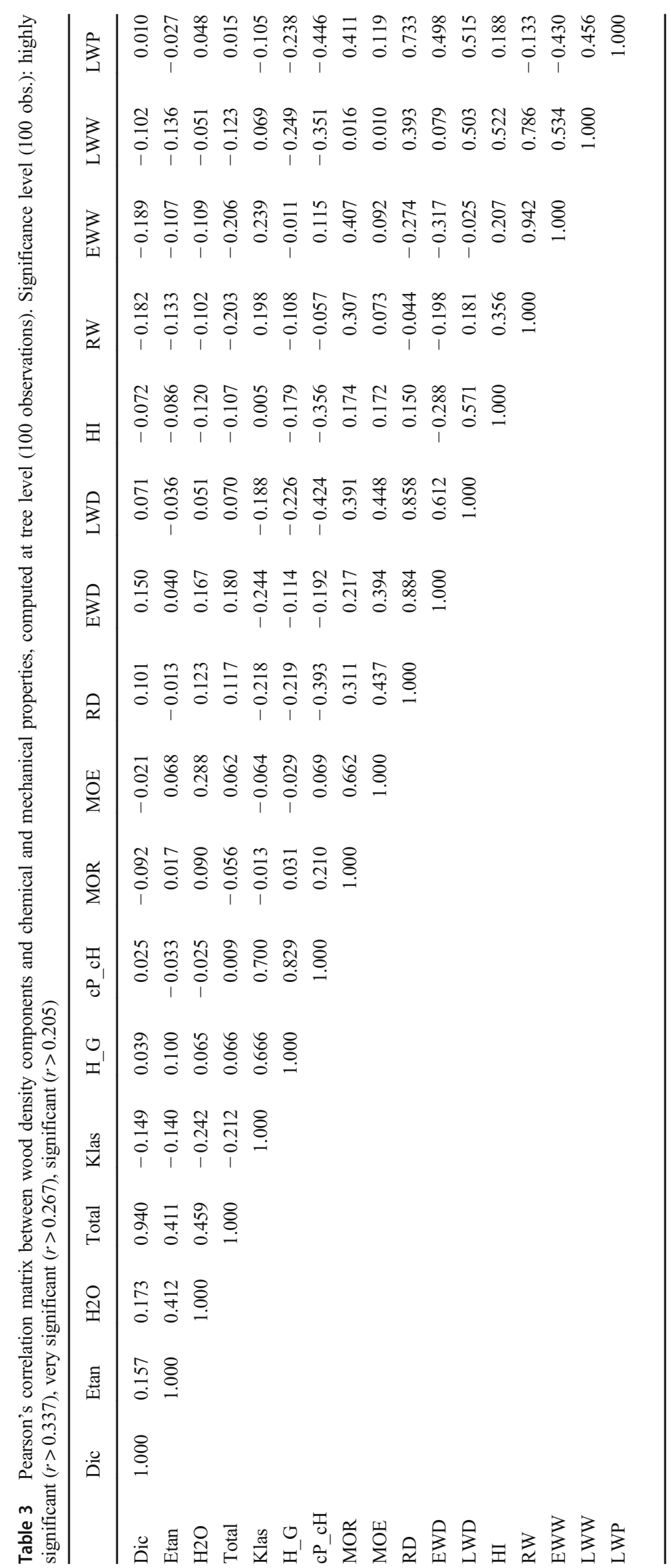


highly significant (RD: -0.393 ; LWD: -0.424 ; HI: -0.356 ; LWW: -0.351 and LWP: -0.446 ).

The correlation between the wood mechanical properties MOR and MOE was positive and highly significant (0.662). A similar result was reported by Gaspar et al. (2011) and Fernandes et al. (2017). This high correlation common to different studies and species allows the evaluation of the strength parameter (MOR) through the stiffness parameter (MOE). Both mechanical properties are also positively and globally highly correlated with the wood density components (RD, EWD and LWD), a fact that was also observed in several species (Niklas 1992; Chave et al. 2009; Gaspar et al. 2011; Missanjo and Matsumura 2016; Fernandes et al. 2017). Similarly to Fernandes et al. (2017) and Gaspar et al. (2011), it was possible to verify that the correlations were higher with $\operatorname{MOE}(0.394$ to 0.448$)$ than with MOR (0.217 to 0.391$)$. Although compared to MOE, MOR presented a lower correlation with the density components, also showing high positive correlations with some of the growth components RW (0.307), EWW (0.407) and LWP (0.411). An identical behaviour was found in P. sylvestris (Fernandes et al. 2017). Likewise, in P. nigra, Amarasekara and Denne (2002) found that the correlation between the mechanical properties and RW was also higher in MOR than in MOE, despite negative.

Regarding the wood density components, $\mathrm{RD}$ showed a similar high positive correlation with EWD (0.884), LWD (0.858) and LWP (0.733), similar to what was found previously by different authors (Koubaa et al. 2000; Louzada 2003; Gaspar et al. 2008; Peltola et al. 2009; Fernandes et al. 2017).

RD showed very significant and negative correlation with EWW (-0.274) (Fig. 1a), which is compensated by the positive and highly significant correlation that was found with LWW (0.393) (Fig. 1b). Thus, RD with RW presents no significant correlation (-0.044) (Fig. 1f), similar to what was obtained by Pritzkow et al. (2014), Fernandes et al. (2017) and Louzada (2003), which might reflect that wood density is not negatively influenced by higher radial growth. On the other hand, other authors found a higher negative correlation between wood density and growth rate in other softwood species (Zhang and Morgenstern 1995; Zhang 1995; Zhang et al. 1996). Nevertheless, this diversity of results can be observed within the same species. In P. radiata, it was found cases of positive correlation (Fielding and Brown 1960), negative correlation (Bannister and Vine 1981; Cown and McConchie 1981) or no correlation at all (Nicholls and Fielding 1964; Bamber and Burley 1983). This fact may be also due to the chosen silvicultural management, which can influence the relationship between wood density and growth rate (Zobel and van Buijtenen 1989) and to the environmental conditions of the site (Zhang and Morgenstern 1995). Moreover, it should be taken into account that the analysis and comparison should be performed within similar age classes due to the distinct wood properties of RW with age. Larger rings with low density are characteristic of juvenile wood, while narrow rings with high density are typical of mature wood (Zobel and van Buijtenen 1989). Also, it was observed a strong correlation of RW with EWW (0.942) (Fig. 1c) and LWW (0.786) (Fig. 1d), similar to the findings of Peltola et al. (2009) and Fernandes et al. (2017). Distinct results are reported by Koubaa et al. (2000). The authors found a very low correlation of RW with LWW, which in this case, the higher radial growth was caused by the earlywood augment. There is no significant correlation between LWP and RW (-0.133) (Fig. 1e), similar to what was previously reported by Guller (2007), while a negative correlation was found in Koubaa et al. (2000), Peltola et al. (2009) and Fernandes et al. (2017), contrarily to a positive correlation observed by Louzada (2003). LWP showed high significant correlations, negative with EWW $(-0.430)$ and positive with LWW (0.456), which means that both components influence the LWP similarly, i.e. with the LWW increases and EWW decreases. Identical outcomings were found by Peltola et al. (2009) and Fernandes et al. (2017), despite in these cases, the EWW had a stronger negative correlation. Similarly, in Koubaa et al. (2000) and Gaspar et al. (2008), there was a strong negative correlation of LWP with EWW, although in LWP with LWW, the positive correlation was stronger.

Concerning the HI, it was possible to verify that was better correlated with LWD (0.571) than with EWD (-0.288), i.e. the increase of $\mathrm{HI}$ is more related with the augment of the latewood density than with the decrease of the earlywood density. Identical behaviour was observed by Louzada (2003) and Fernandes et al. (2017).

\section{Conclusion}

In what concerns to the chemical analysis, this species presented higher values of extractive content and similar Klason lignin content when compared to the reference values for softwood species. In addition, the $\mathrm{H} / \mathrm{G}$ ratio was similar to the performed studies but slightly lower than $P$. pinaster.

The mechanical properties, MOR and MOE, tend to present similar values compared to other conifers. Moreover, these mechanical properties were not related to the geographic location (latitude and altitude).

Regarding the relationships between the chemical properties of wood, the higher correlation was found between total extractives and dichloromethane, as well as between ethanol and water, which is in agreement with other studies conducted in different pine species present in Portugal. Klason lignin was highly correlated with $\mathrm{H} / \mathrm{G}$ and $\mathrm{cP} \_\mathrm{cH}$, and the latter two were strongly correlated between them as well.

The correlation between the two radial mechanical properties of wood, MOR and MOE, was highly significant, as expected, and both were significantly correlated with the wood 

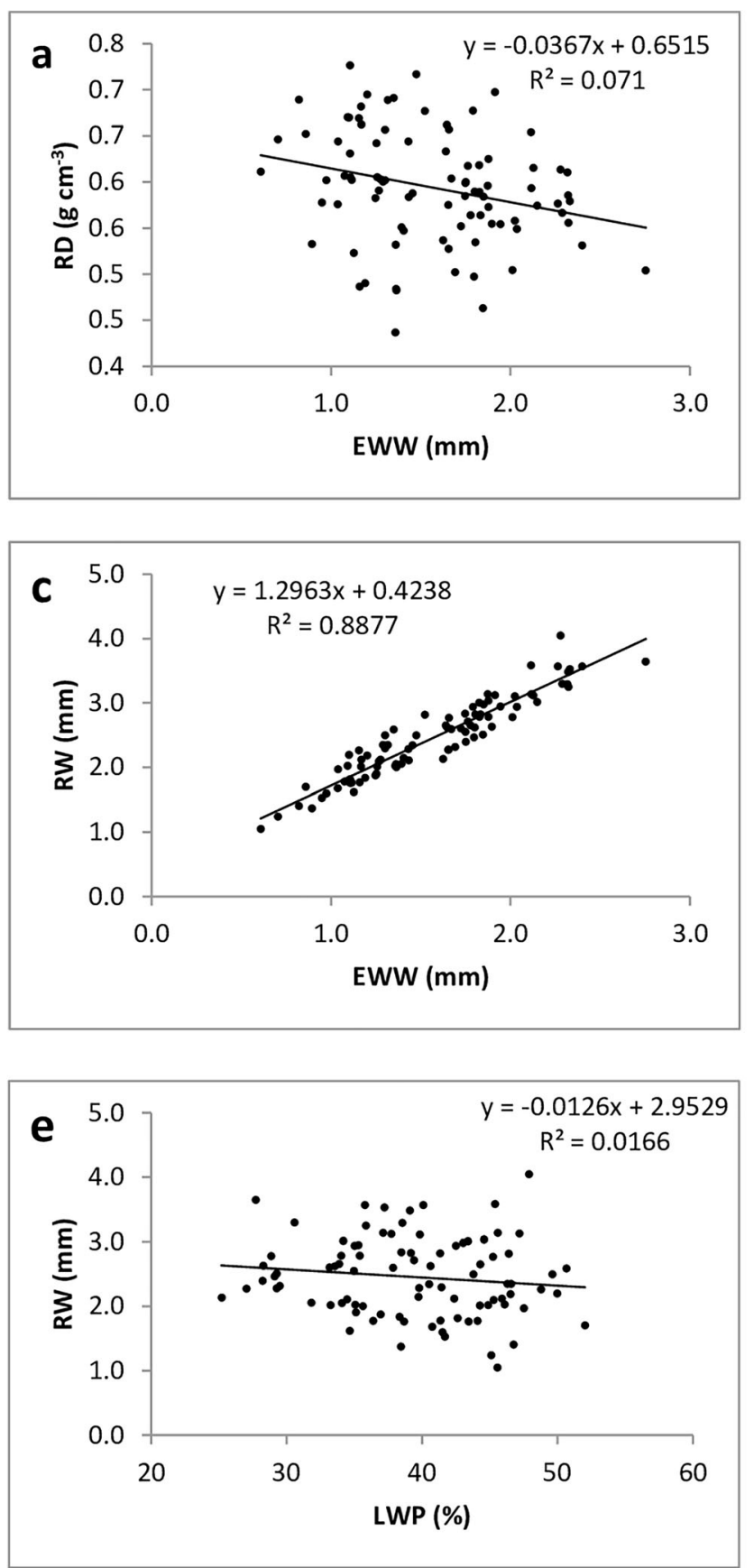

Fig. 1 Linear regression between ring density and ring width components

density components, similar to other studies. The relationship with the wood growth components was lower, but a higher correlation between MOR and RW, and EWW and LWP was found.

As to the correlation of the wood density components, RD presented similar high correlation to EWD and LWD. Concerning the radial growth, it showed no significant correlation with $\mathrm{RD}$, reflecting that wood density is not negatively influenced by growth. HI is more correlated with LWD (positively) than EWD (negatively).
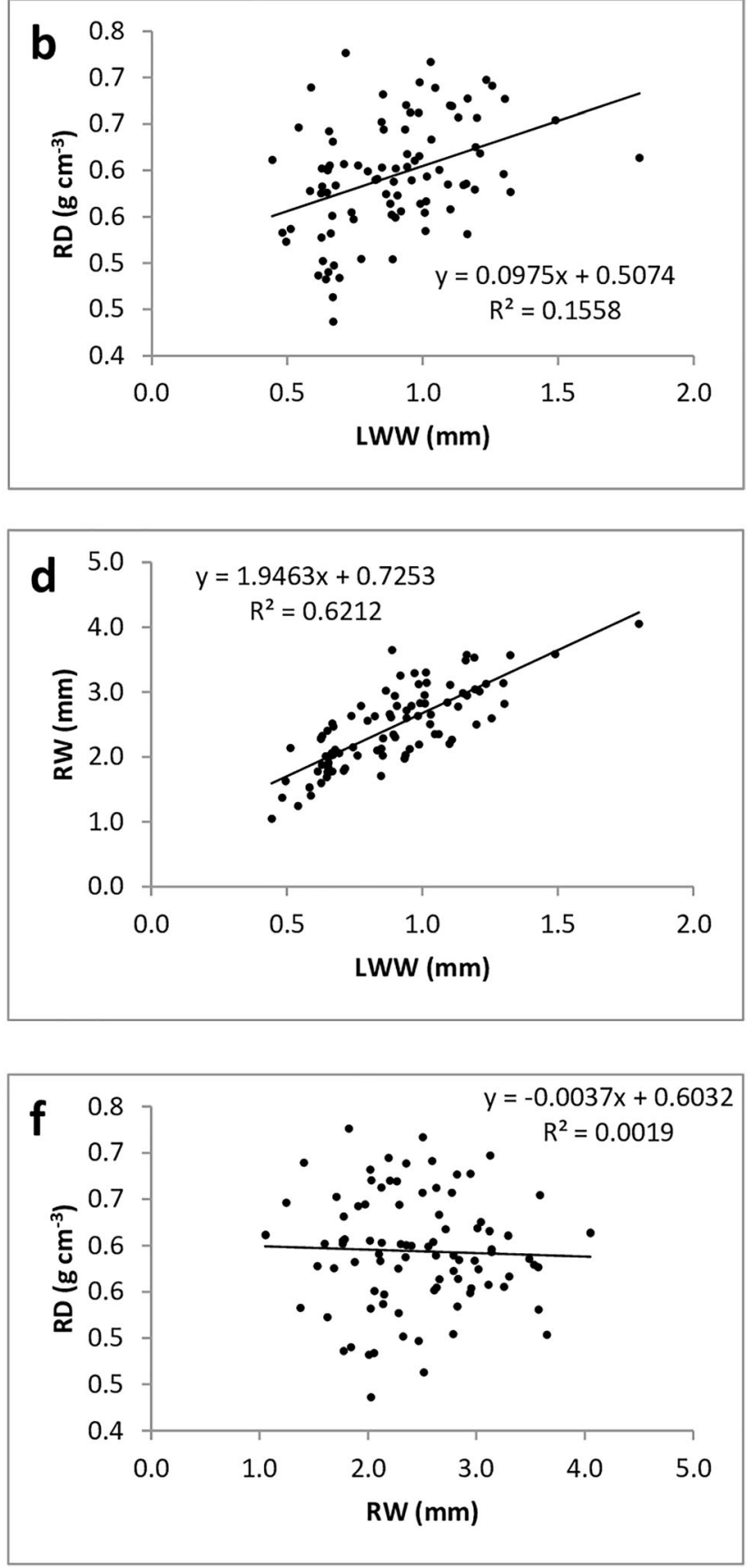

Facing the reduction of the $P$. pinaster forest area that constitutes the main species used for industrial purposes in Portugal, as well as the increasing timber demands and importation of wood, $P$. nigra could be used for the reforestation of mountainous areas. These areas are widely deforested and are not suited for $P$. pinaster reforestation. Therefore, $P$. nigra could constitute an alternative and essential source to supply the Portuguese forestry industry. Besides, as revealed with this work, the $P$. nigra wood, compared to $P$. pinaster with similar age, showed identical or slightly higher wood density components, similar growth rate, higher total extractive content, 
lower Klason lignin and $\mathrm{H} / \mathrm{G}$ ratio and similar mechanical properties.

Acknowledgements We thank the centre grants UIDB/04046/2020 and UIDP/04046/2020 that were attributed to the BioISI research unit by the Portuguese Foundation for the Science and Technology (FCT - Fundação para a Ciência e a Tecnologia). The author A.C. thanks the FCT and UTAD for her contract as researcher under the scope of the D.L. no. 57/2016 of 29 August and Law no. 57/2017 of 19 July.

Funding This work was funded by national funds provided by the FCT Fundação para a Ciência e a Tecnologia) to CITAB under the project UIDB/04033/2020 and to the author A.D. by the attribution of the doctoral grant SFRH/BD/91781/2012, co-financed by the Social European Fund (FSE) under the POPH-QREN program.

Data availability The datasets generated during and/or analysed during the current study are available in the figshare repository [https://doi.org/ $10.6084 / \mathrm{m} 9$. figshare.12185223]

\section{Compliance with ethical standards}

Conflict of interest The authors declare that they have no conflicts of interest.

\section{References}

Afzal-Rafii Z, Dodd RS (2007) Chloroplast DNA supports a hypothesis of glacial refugia over postglacial recolonization in disjunct populations of black pine (Pinus nigra) in western Europe: Phylogeography of European black pine. Mol Ecol 16:723-736. https://doi.org/10.1111/j.1365-294X.2006.03183.x

Alves A, Schwanninger M, Pereira H, Rodrigues J (2006) Calibration of NIR to assess lignin composition (H/G ratio) in maritime pine wood using analytical pyrolysis as the reference method. Holzforschung 60:29-31. https://doi.org/10.1515/HF.2006.006

Alves A, Simões R, Lousada JL, Lima-Brito J, Rodrigues J (2019) Predicting the lignin $\mathrm{H} / \mathrm{G}$ ratio of Pinus sylvestris L. wood samples by PLS-R models based on near-infrared spectroscopy. Holzforschung 0:1-8. https://doi.org/10.1515/hf-2019-0186

Amarasekara H, Denne MP (2002) Effects of crown size on wood characteristics of Corsican pine in relation to definitions of juvenile wood, crown formed wood and core wood. Forestry 75:51-61. https://doi.org/10.1093/forestry/75.1.51

Bamber RK, Burley J (1983) The wood properties of radiata pine. Commonwealth Agricultural Bureaux

Bannister MH, Vine MH (1981) An early progeny trial in Pinus radiata 4. Wood density. N Z J For Sci 11:221-243

Barbéro M, Loisel R, Quézel P et al (1998) Ecology and biogeography of Pinus. Cambridge University Press, South Africa, David M. Richardson

Brancheriau L, Bailleres H, Guitard D (2002) Comparison between modulus of elasticity values calculated using 3 and 4 point bending tests on wooden samples. Wood Sci Technol 36:367-383. https://doi.org/ 10.1007/s00226-002-0147-3

Brazier J, Howell R (1979) The use of a breast height core for estimating selected whole tree properties of Sitka spruce. Forestry 52:177-185

Campbell M, Sederoff RR (1996) Variation in lignin content and composition - mechanisms of control and implications for the genetic improvement of plants. Plant Physiol 110:3-13
Cave I, Walker J (1994) Stiffness of wood in fast-grown plantation softwoods: the influence of microfibril angle. For Prod J 44:43-48

Chave J, Coomes D, Jansen S, Lewis SL, Swenson NG, Zanne AE (2009) Towards a worldwide wood economics spectrum. Ecol Lett 12:351366. https://doi.org/10.1111/j.1461-0248.2009.01285.x

Cown DJ, McConchie DL (1981) Effects of thinning and fertiliser application on wood properties of Pinus radiata. N Z J For Sci 11:79-91

Cruz N, Bustos CA, Aguayo MG, Cloutier A, Castillo R (2018) Impact of the chemical composition of Pinus radiata wood on its physical and mechanical properties following thermo-hygromechanical densification. BioResources 13:2268-2282. https://doi.org/10.15376/ biores.13.2.2268-2282

del Cerro BA, Borja ML, Garcia EM et al (2009) Influence of stand density and soil treatment on the Spanish black pine (Pinus nigra Arn. ssp. salzmannii) regeneration in Spain. For Syst 18:167-180

Dias A, Carvalho A, Silva ME et al (2020) Wood properties database chemical properties, mechanical properties and physical properties. Figshare [Dataset]. https://doi.org/10.6084/m9.figshare.12185223. v1

Dias A, Gaspar MJ, Carvalho A, Pires J, Lima-Brito J, Silva ME, Louzada JL (2018) Within- and between-tree variation of wood density components in Pinus nigra at six sites in Portugal. Ann For Sci 75:58. https://doi.org/10.1007/s13595-018-0734-6

Dias A, Lemos M, Pavia I, Gaspar MJ, Silva ME, Louzada JL, LimaBrito J, Carvalho A (2019) Genetic characterization of Portuguese allochthonous populations of Pinus nigra using ISSRs and SCoTs and extrapolation of their infraspecific taxonomy. Physiol Mol Biol Plants 25:1-7. https://doi.org/10.1007/s12298-019-00649-5

Downes G, Evans R, Schimleck L, Fritts H (2000) The commercial cambium: understanding the origin of wood property variation. Cell Mol Biol Wood Form 123:325-336

Elliot G (1970) Wood density in conifers., technical communication no 8 . Commonwealth Forestry Bureau, Oxford, England

Fernandes C (2008) Avaliação da interacção genótipo x ambiente nas características de qualidade da madeira de Pinus pinaster [Evaluation of genotype $\mathrm{x}$ environment interaction in Pinus pinaster wood quality characteristics]. University of Tras-os- Montes and Alto Douro

Fernandes C, Gaspar M, Pires J, Alves A, Simões R, Rodrigues JC, Silva ME, Carvalho A, Brito JE, Lousada JL (2017) Physical, chemical and mechanical properties of Pinus sylvestris wood at five sites in Portugal. IForest - Biogeosciences For 10:669-679. https://doi.org/ 10.3832 /ifor $2254-010$

Fernández-Golfín Seco JI, Diez Barra MR, Hermoso Prieto E, Conde García M (2004) Mechanical characterization of timber from Spanish provenances of laricio pine according to European standards. Wood Sci Technol 38:25-34. https://doi.org/10.1007/ s00226-003-0215-3

Fielding JM, Brown AG (1960) Variation in the density of the wood of Monterey pine from tree to tree. Canberra

Gaspar MJ, Alves A, Louzada JL, Morais J, Santos A, Fernandes C, Almeida MH, Rodrigues JC (2011) Genetic variation of chemical and mechanical traits of maritime pine (Pinus pinaster Aiton). Correlations with wood density components. Ann For Sci 68:255265. https://doi.org/10.1007/s13595-011-0034-x

Gaspar MJ, Louzada JL, Aguiar A, Almeida MH (2008) Genetic correlations between wood quality traits of Pinus pinaster Ait. Ann For Sci 65:703-703. https://doi.org/10.1051/forest:2008054

Génova M, Cancio Á (1998) Tree rings and climate of Pinus nigra subsp. salzmannii in central Spain. Dendrochronologia 16-17:75-85

Godoy E, Rodrigues J, Alves AM, Lazo D (2007) Estudio del contenido y la calidad de la lignina mediante Pirólisis analítica en madera de Pinus caribaea. Maderas Cienc Tecnol 9:179-188. https://doi.org/ 10.4067/S0718-221X2007000200008

Gomide JL, Colodette JL, de Oliveira RC, Silva CM (2005) Caracterização tecnológica, para produção de celulose, da nova 
geração de clones de Eucalyptus do Brasil. Rev Árvore 29:129-137. https://doi.org/10.1590/S0100-67622005000100014

Green DW, Winandy JE, Kretschmann DE (1999) Wood handbook wood as an engineering material. Department of Agriculture, Forest Service

Guller B (2007) The effects of thinning treatments on density, MOE, MOR and maximum crushing strength of Pinus brutia Ten. wood. Ann For Sci 64:467-475. https://doi.org/10.1051/forest:2007024

Hafizoglu H (1983) Wood extractives of Pinus sylvestris L., Pinus nigra Arn and Pinus brutia Ten. Holzforschung 37:321-326

Hannrup B, Cahalan C, Chantre G, Grabner M, Karlsson B, Bayon IL, Jones GL, Müller U, Pereira H, Rodrigues JC, Rosner S, Rozenberg P, Wilhelmsson L, Wimmer R (2004) Genetic parameters of growth and wood quality traits in Picea abies. Scand J For Res 19:14-29. https://doi.org/10.1080/02827580310019536

Koga S, Zhang SY (2004) Inter-tree and intra-tree variations in ring width and wood density components in balsam fir (Abies balsamea). Wood Sci Technol 38:149-162. https://doi.org/10.1007/s00226004-0222-Z

Koubaa A, Zhang SY, Isabel N et al (2000) Phenotypic correlations between juvenile-mature wood density and growth in black spruce. Wood Sci 32:61-71

Louro V (1982) O pinheiro laricio: Pinus nigra Arnold em Portugal. Direccao geral do ordenamento e gestao florestal, Lisboa

Louzada JLPC (2003) Genetic correlations between wood density components in Pinus pinaster Ait. Ann For Sci 60:285-294. https://doi. org/10.1051/forest:2003020

Louzada JLPC, Fonseca FMA (2002) The heritability of wood density components in Pinus pinaster Ait. and the implications for tree breeding. Ann For Sci 59:867-873. https://doi.org/10.1051/forest: 2002085

Missanjo E, Matsumura J (2016) Wood density and mechanical properties of Pinus kesiya Royle ex Gordon in Malawi. Forests 7:135. https://doi.org/10.3390/f7070135

Nanayakkara B, Riddell MJ, Harrington J (2015) Screening of juvenile Pinus radiata wood by means of Py-GC/MS for compression wood focussing on the ratios of p-hydroxyphenyl to guaiacyl units $(\mathrm{H} / \mathrm{G}$ ratios). Holzforschung 70:313-321. https://doi.org/10.1515/hf2015-0068

Naydenov KD, Tremblay FM, Fenton NJ, Alexandrov A (2006) Structure of Pinus nigra Arn. populations in Bulgaria revealed by chloroplast microsatellites and terpenes analysis: provenance tests. Biochem Syst Ecol 34:562-574. https://doi.org/10.1016/j.bse.2006. 01.011

Nicholls JW, Fielding JM (1964) The effect of growth rate on wood characteristics. CSIRO 19:24-30

Niklas KJ (1992) An engineering approach to plant form and function. University of Chicago Press

Ohbayashi H, Booker RE, Ball RD, Ridoutt BG (2001) Radial modulus of rupture in radiata pine measured by individual rings. J Wood Sci 47:233-236. https://doi.org/10.1007/BF01171227

Panshin A, Zeeuw C (1980) Textbook of wood technology, 4ed edn. Mc Graw-Hill, New York

Peltola H, Gort J, Pulkkinen P, et al (2009) Differences in growth and wood density traits in Scots pine (Pinus sylvestris L.) genetic entries grown at different spacing and sites

Pritzkow C, Heinrich I, Grudd H, Helle G (2014) Relationship between wood anatomy, tree-ring widths and wood density of Pinus sylvestris $\mathrm{L}$. and climate at high latitudes in northern Sweden. Dendrochronologia 32:295-302. https://doi.org/10.1016/j.dendro. 2014.07.003

Reva V, Fonseca L, Lousada JL, Abrantes I, Figueiredo AR, Viegas DX (2015) Basic density, extractive content and moisture sorption properties of Pinus pinaster wood infected with the pinewood nematode, Bursaphelenchus xylophilus. J For Res 26:233-240. https://doi.org/ 10.1007/s11676-015-0024-1
Rubio-Moraga A, Candel-Perez D, Lucas-Borja ME, Tiscar PA, Viñegla B, Linares JC, Gómez-Gómez L, Ahrazem O (2012) Genetic diversity of Pinus nigra Arn. populations in southern Spain and northern Morocco revealed by inter-simple sequence repeat profiles. Int $\mathrm{J}$ Mol Sci 13:5645-5658. https://doi.org/10.3390/ijms13055645

Sable I, Grinfelds U, Jansons A, Vikele L, Irbe I, Verovkins A, Treimanis A (2012) Properties of wood and pulp fibers from lodgepole pine (Pinus contorta) and scots pine (Pinus sylvestris). BioResources 7: 1771-1783. https://doi.org/10.15376/biores.7.2.1771-1783

Santos JA, Pinho ACM (2004) New advances for the application of Eucalyptus as a structural wood. Silva Lusit 12:43-50

Schwanninger M, Rodrigues JC, Gierlinger N, Hinterstoisser B (2011a) Determination of lignin content in Norway spruce wood by Fourier transformed near infrared spectroscopy and partial least squares regression. Part 1: wavenumber selection and evaluation of the selected range. J Infrared Spectrosc 19:319-329. https://doi.org/10.1255/ jnirs.944

Schwanninger M, Rodrigues JC, Gierlinger N, Hinterstoisser B (2011b) Determination of lignin content in Norway spruce wood by Fourier transformed near infrared spectroscopy and partial least squares regression analysis. Part 2: development and evaluation of the final model. J Infrared Spectrosc 19:331-341. https://doi.org/10.1255/ jnirs.945

Sjöström E, Alén R (2013) Analytical methods in wood chemistry, pulping, and papermaking. Springer Series in Wood Science, Springer-Verlag Berlin Heidelberg

Thompson J (2005) The geographic mosaic of coevolution. University of Chicago Press, Chicago

Toivanen T, Alén R (2006) Variations in the chemical composition within pine (Pinus sylvestris) trunks determined by diffuse reflectance infrared spectroscopy and chemometrics. Cellulose 13:53-61. https://doi.org/10.1007/s10570-005-9016-1

Tsoumis G (1991) Science and technology of wood: structure, properties, utilization, Reprint of the ed. New York 1991. Kessel, RemagenOberwinter

Uçar G, Balaban M (2002) Cyclohexane extracts of black pine wood naturally grown in eastern Thrace. Holz Als Roh- Werkst 60:34 40. https://doi.org/10.1007/s00107-001-0251-3

Uçar G, Fengel D (1995) Variation in composition of extractives from wood of Pinus nigra varieties. Phytochemistry 38:877-880. https:// doi.org/10.1016/0031-9422(94)00734-B

Üner B, Karaman I, Tanriverdi H, Özdemir D (2009) Prediction of lignin and extractive content of Pinus nigra Arnold. var. Pallasiana tree using near infrared spectroscopy and multivariate calibration. J Wood Chem Technol 29:24-42. https://doi.org/10.1080/ 02773810802607567

Üner B, Karaman I, Tanrıverdi H, Özdemir D (2011) Determination of lignin and extractive content of Turkish Pine ( Pinus brutia Ten.) trees using near infrared spectroscopy and multivariate calibration. Wood Sci Technol 45:121-134. https://doi.org/10.1007/s00226010-0312-z

Uva J (2015) Inventário Florestal Nacional - A dinâmica da ocupação florestal do solo desde o séc. XIX a 2050. Inst. Conserv. Nat. E Florestas P ICNF 2:83

Vainio-Kaila T, Zhang X, Hänninen T et al (2017) Antibacterial effects of wood structural components and extractives from Pinus sylvestris and Picea abies on methicillin-resistant Staphylococcus aureus and Escherichia coli O157:H7. BioResources 12:14

Yildirim H, Holmbom B (1978) Investigations on the wood extractives of pine species from Turkey. I. Unsaponifiable, nonpolar components in Pinus silvestris and Pinus nigra. Acta Acad Abo 37:

Yoshihara H, Tsunematsu S (2006) Feasibility of estimation methods for measuring Young's modulus of wood by three-point bending test. Mater Struct 39:29-36. https://doi.org/10.1617/s11527-005-9015-6

Zhang S, Morgenstern E (1995) Genetic variation and inheritance of wood density in black spruce (Picea mariana) and its relationships 
with growth: implications for tree breeding. Wood Sci Technol 30: 63-75. https://doi.org/10.1007/BF00195269

Zhang SY (1995) Effect of growth rate on wood specific gravity and selected mechanical properties in individual species from distinct wood categories. Wood Sci Technol 29:. https://doi.org/10.1007/ BF00194204

Zhang SY, Simpson D, Morgenstern E (1996) Variation in the relationship of wood density with growth in 40 black spruce (Picea mariana) families grown in New Brunswick. Wood Fibre Sci 28: 91-99
Zobel BJ, Sprague JR (1998) Juvenile wood in forest trees. Springer, Berlin Heidelberg, Berlin, Heidelberg

Zobel BJ, van Buijtenen JP (1989) Wood variation. Springer, Berlin Heidelberg, Berlin, Heidelberg

Publisher's note Springer Nature remains neutral with regard to jurisdictional claims in published maps and institutional affiliations.

\section{Affiliations}

\section{Alexandra Dias ${ }^{1}$ - Ana Carvalho 1,2,3 - Maria Emília Silva ${ }^{1,4}$ • José Lima-Brito 1,2,3 Maria João Gaspar $^{2,3,5}$ • Ana Alves ${ }^{5}$. José Carlos Rodrigues ${ }^{5} \cdot$ Fábio Pereira $^{1} \cdot$ José Morais $^{1} \cdot$ José Luís Lousada $^{1,4}$}

1 Center of Research and Technology of Agroenvironmental and Biological Sciences (CITAB), University of Tras-os-Montes and Alto Douro, Quinta de Prados, 5000-801 Vila Real, Portugal

2 Biosystems \& Integrative Sciences Institute, University of Trás-osMontes and Alto Douro (BioISI - UTAD), Quinta de Prados, 5000801 Vila Real, Portugal
3 Department of Genetics and Biotechnology, University of Trás-osMontes and Alto Douro, Quinta de Prados, 5000-801 Vila Real, Portugal

4 Department of Forestry Sciences and Landscape (CIFAP), University of Trás-os-Montes and Alto Douro, Quinta de Prados, 5000-801 Vila Real, Portugal

5 Forest Research Centre (CEF), Instituto Superior de Agronomia (ISA), University of Lisbon, Lisbon, Portugal 